\title{
Sikap Masyarakat Terhadap Fenomena Kekerasan pada Perempuan dan Anak di Nagari Siguntur, Kabupaten Pesisir Selatan
}

\author{
Elsa Mulya Agustin, Fatmariza \\ Prodi Pendidikan Pancasila dan Kewarganegaraan \\ FIS Universitas Negeri Padang \\ E-mail: fatmariza@fis.unp.ac.id
}

\section{ABSTRAK}

Kekerasan terhadap perempuan dan anak cenderung meningkat dari tahun ke tahun. Berangkat dari permasalahan tersebut, penelitian ini bertujuan untuk mendiskripsikan sikap masyarakat terhadap kekerasan pada perempuan dan anak. Jenis penelitian ini adalah deskriptif kuantitatif. Lokasi penelitian ini di Nagari Siguntur, Kecamatan Koto XI Tarusan, Kabupaten Pesisir Selatan. Responden berjumlah 97 orang yang dipilih menggunakan teknik probability sampling. Teknik pengumpulan data dalam penelitian ini menggunakan kuesioner berupa angket penelitian serta wawancara sebagai pendukung hasil angket penelitian. Uji validitas dan reliabilitas menggunakan aplikasi SPSS 19. Hasil penelitianmenunjukan bahwa sikap masyarakat terhadap kekerasan yang diukur dari indikator bentuk-bentuk kekerasan, faktor penyebab kekerasan, pencegahan/penyelesaian kekerasan antara laki-laki dan perempuan menunjukan hasil yang berbeda. Terlihat bahwa sikap laki-laki lebih baik dari pada sikap perempuan dengan persentase sikap perempuan 65,23\% sedangkan laki-laki 65,75\%. Dilihat dari indikator bentuk kekerasan yang lebih dikenali dan diketahui masyarakat adalah kekerasan fisik. Sementara itu faktor yang menjadi penyebab utama kekerasan adalah budaya patriaki. Pencegahan dan penyelesaian kekerasan dapat dilakukan dengan mengadakan sosialisasi dan memberikan pendidikan sejak dini kepada anak.

Kata Kunci: kekerasan perempuan dan anak, patriarki, Siguntur, Pesisir Selatan

\section{ABSTRACT}

Violence against women and children tends to increase. This study aims to describe people's attitudes towards violence against women and children. This type of research is descriptive quantitative. The location of this research is Nagari Siguntur, Koto XI Tarusan District, Pesisir Selatan Regency. The total respondents are 97 people who were selected using probability sampling technique. Data collection techniques in this study used form of research questionnaires and interviews. The test of validity and reliability using the SPSS 19 application. The results showed that people's attitudes towards violence as measured by indicators of forms of violence, factors causing violence, prevention/resolving of violence between men and women showed different results. It can be seen that the attitude of men is better than the attitude of women with the percentage of women's attitudes $65.23 \%$ while men's $65.75 \%$. Physical violence are more recognizable and known to the public. 
Meanwhile, the main cause of violence is patriarchal culture. Prevention and resolution of violence can be done by conducting socialization and providing early education to children. Keywords: women and children violence, patriarchy, Siguntur, Pesisir Selatan

\section{PENDAHULUAN}

Kekerasan yang terjadi terhadap perempuan dan anak cenderung meningkat setiap tahunnya (Santoso, 2019). Berdasarkan data dari Komnas Perempuan serta Dinas Sosial Pemberdayaan Perempuan dan Anak kota Painan terlihat bahwa kekerasan yang terjadi pada perempuan dan anak meningkat setiap tahunnya dengan kasus kekerasan tahun 2019 terjadi 98 kasus. (Kekerasan, Perempuan, \& Perempuan, 2020). Adapun data kasus kekerasan yang tercatat dari Komnas Perempuan, 2020 sebagai berikut :

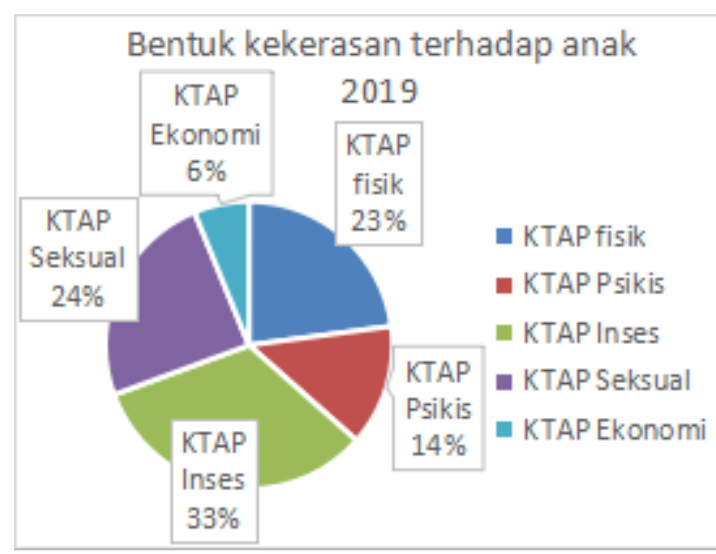

Diagram 1. Bentuk Kekerasan Terhadap Anak (Komnas Perempuan, 2019)

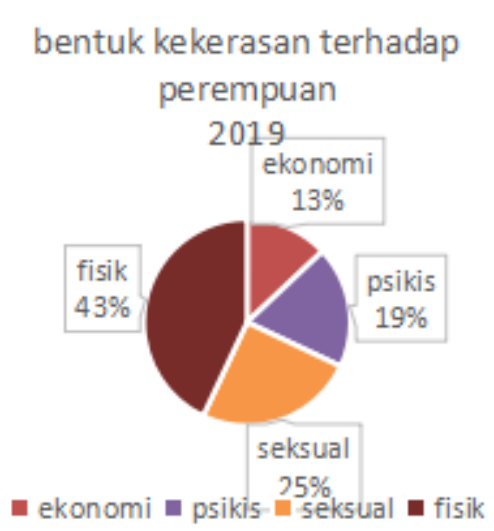

Diagram 2. Bentuk Kekerasan Terhadap Perempuan (Komnas Perempuan, 2019) Kekerasan merupakan tindakan yang menimbulkan penderitaan secara fisik, seksual, psikologis serta ekonomi bagi korban (UU No 23 Tahun 2004). Penelitian terkait dari (Rifa, 2019) mengungkapkan bahwa kekerasan perempuan terjadi karena rendahnya pola pola pikir masyarakat tentang persamaan derajat laki-laki maupun perempuan. (Andini et al., 2019) mengungkapkan bahwa kekerasan cenderung terjadi pada anak berusia 11 tahun ke atas yang didominasi oleh kekerasan fisik.

Penelitian ini bertujuan untuk melihat pandangan laki-laki dan perempuan terhadap tindakan kekerasan. Unsur yang diteliti adalah bentuk tindakan kekerasan, faktor penyebab, serta pencegahan yang terjadi di masyarakat. Menurut UU 
No. 23 tahun 2004 tentang Penghapusan Kekerasan dalam Rumah Tangga mengungkapkan bahwa kekerasan merupakan perbuatan yang dilakukan oleh manusia kepada manusia lainnya secara individu, kelompok yang menyebabkan pihak yang satu merasa tersakiti baik secara fisik maupun non fisik (Santoso, 2019). Adapun bentuk kekerasan terbagi menjadi; kekerasan fisik, kekerasan seksual, kekerasan psikologis, dan penelantaran rumah tangga/kekerasan ekonomi.

Kekerasan fisik dapat berupa tindakan memukul, menendang dan sebagainya yang dapat meninggalkan bekas fisik. Kekerasan psikologis merupakan perbuatan yang mengakibatkan ketakutan, hilangnya rasa percaya diri, hilangnya kemampuan untuk bertindak, rasa tidak berdaya, dan/atau penderitaan psikis berat pada seseorang (Santoso, 2019). Sementara itu, kekerasan seksual merupakan perbuatan pemaksaan hubungan seksual dengan cara tidak wajar atau tidak disukai. Selanjutnya kekerasan ekonomi dapat berupa tindakan penelantaran, tidak memberi nafkah dan memaksa anak dibawah usia 18 tahun bekerja (Andini et al., 2019).

Kekerasan perempuan dan anak disebabkan oleh beberapa faktor; a) budaya patriarki yang masih kental dipahami dan dipercaya oleh masyarakat, b) pemahaman yang keliru terhadap ajaran agama, c) peniruan terhadap masa lalu yang dilihat dari orang terdekat seperti orang tua, teman, dan masyarakat di lingkungan tempat tinggal mereka (Hasanah, 2013). Selain itu, kekerasan terhadap perempuan dan anak di pedesaan jarang tercatat dan dilaporkan (Fatmariza, 2020).

\section{METODE PENELITIAN}

Penelitian ini menggunakan metode kuantitatif deskriptif. Metode kuantitatif menekankan kepada angka-angka hasil pengukuran berdasarkan analisis tertentu dengan tujuan untuk membuktikan suatu fenomena (Iii, Penelitian, \& Moleong, n.d.). Sumber data yang digunakan adalah data primer, yaitu data langsung yang diperoleh dari pernyataan kuesioner, wawancara dan data sekunder yang tidak langsung diperoleh dari pihak pertama (Hermawan, n.d.).

Penelitian ini menggunakan teknik pengumpulan data kuesioner berupa angket penelitian dan didukung dengan wawancara. Menurut (Sugiyono, 2010) kuesioner merupakan teknik pengumpulan data yang dilakukan dengan memberikan pernyataan tertulis kepada responden. Sampel penelitian diambil menggunakan teknik probability sampling berupa cluster sampling dengan memberikan peluang yang sama bagi setiap responden. Sampel penelitian berjumlah 97 orang yang didapat dengan rumus slovin.

Uji validitas dalam penelitian ini menggunakan softwere statistical product and service solution (SPSS) versi 19 yang dilihat dari Corrected ItemTotal Correlation dengan hasil $\mathrm{r}$ tabel besar dari 0,361 maka dinyatakan valid. Sedangkan reabilitas dalam penelitian ini menggunakan ketentuan Cronbach Alpha dengan hasil $r$ tabel besar dari 0,6 maka dinyatakan reliabel. Dari hasil pengolahan data didapatkan bahwa 
Volume 4 No. 22021

30 pernyataan yang diberikan dinyatakan valid dan reliabel.

Hasil analisis data yang digunakan dalam penelitian ini menggunakan rumus persentase sebagai berikut :

$p=\frac{\mathrm{F}}{\mathrm{N}} \times 25=100 \%$

Teknik ini bertujuan untuk menggambarkan data sampel.

Lokasi penelitian adalah di Kanagarian Siguntur, Kecamatan Koto XI Tarusan, Kabupaten Pesisir Selatan. Alasan pengambilan lokasi ini karena di Nagari ini terdapat banyak kasus kekerasan perempuan dan anak di tahun 2019. Pertimbangan lainnya adalah biaya penelitian dan keterjangkauan dalam mengakses lokasi penelitian.

\section{HASIL DAN PEMBAHASAN}

Sikap masyarakat terhadap kekerasan pada perempuan dan anak di Nagari Siguntur diukur dari beberapa unsur; bentuk kekerasan, faktor penyebab kekerasan, serta pencegahan dan penyelesaiannya.

Menurut UU No. 23 Tahun 2004 tentang kekerasan dalam rumah tangga diungkapkan bahwa bentuk kekerasan terhadap perempuan dan anak dapat dibedakan menjadi; kekerasan fisik, kekerasan psikologis, kekerasan seksual, kekerasan ekonomi. Kekerasan fisik merupakan bentuk kekerasan yang dapat menimbulkan kerusakan dan rasa sakit secara fisik (Andini et al., 2019). Berdasarkan data kuesioner penelitian yang disebarkan kepada responden terlihat bahwa sikap masyarakat baik laki-laki dan perempuan terhadap tindakan kekerasan fisik berada pada kategori setuju dengan persentase hasil pengetahuan perempuan $81,62 \%$ sedangkan pengetahuan laki-laki
$71,75 \%$ dengan kategori setuju. Artinya bahwa kekerasan fisik sudah dikenali dan diketahui oleh masyarakat.

Sementara itu, kekerasan psikologis merupakan bentuk kekerasan non-fisik artinya tindakan yang dilakukan dapat mengancam, menimbulkan ketakutan dan hilangnya rasa percaya diri seseorang sehingga mengganggu kesehatan mental korban (Santoso, 2019). Dari hasil perolehan penelitian menunjukan bahwa kekerasan psikologis belum begitu disadari oleh masyarakat karena kekerasan ini tidak tampak secara fisik sehingga sulit dikenali secara langsung dari luar. Hasil penelitian menunjukkan bahwa sikap laki-laki yang setuju sebesar $57,28 \%$ sedangkan perempuan $60,57 \%$ berada pada kategori tidak setuju.

Kekerasan seksual dapat terjadi dalam lingkup rumah tangga dan lingkungan umum. Kekerasan seksual dalam rumah tangga cenderung belum disadari oleh masyarakat terutama perempuan (Umriana, Fauzi, \& Hasanah, 2016). Hasil penelitian menunjukan bahwa pemahaman perempuan lebih rendah dari pada laki-laki dengan persentase pengetahuan perempuan $56,75 \%$ sedangkan laki-laki 59,58\%. Hal ini berarti kekerasan seksual belum dikenal oleh masyarakat bahkan jika terjadi dalam lingkup rumah tangga kekerasan ini dianggap wajar oleh perempuan (Surtinah, 2017).

Menurut (Santoso,2019) kekerasan ekonomi atau kekerasan dalam penelantaran dalam rumah tangga dapat berupa melarang bekerja, tidak memberikan nafkah, serta pembatasan dalam memberikan uang belanja kepada keluarga. Berdasarkan 
pengolahan data penelitian terlihat bahwa sikap perempuan dalam mendeskripsikan kekerasan lebih tinggi dari laki-laki dengan persentase pengetahuan perempuan $64,25 \%$ serta laki-laki 59,43\%. Artinya bahwa sikap masyarakat masih rendah, masyarakat belum menyadari pelarangan yang diberikan suami dan ayah terhadapnya merupakan tindakan kekerasan.

Dari bentuk kekerasan di atas dapat diungkapkan bahwa pengetahuan masyarakat terhadap bentuk-bentuk kekerasan masih rendah. Hal ini dijelaskan dalam tabel berikut:

\begin{tabular}{|c|c|c|c|c|}
\hline No & $\begin{array}{l}\text { Pernyataa } \\
\mathrm{n}\end{array}$ & $\begin{array}{l}\text { Rata } \\
\text {-rata }\end{array}$ & $\%$ & $\begin{array}{l}\text { Kategor } \\
\mathrm{i}\end{array}$ \\
\hline 1 & $\begin{array}{l}\text { Kekerasan } \\
\text { fisik }\end{array}$ & 3,26 & $\begin{array}{l}81,6 \\
2\end{array}$ & Setuju \\
\hline 2 & $\begin{array}{l}\text { Kekerasan } \\
\text { psikologis }\end{array}$ & 2,42 & $\begin{array}{l}60.5 \\
7\end{array}$ & $\begin{array}{l}\text { Tidak } \\
\text { setuju }\end{array}$ \\
\hline 3 & $\begin{array}{l}\text { Kekerasan } \\
\text { seksual }\end{array}$ & 2,89 & $\begin{array}{l}56,7 \\
5\end{array}$ & $\begin{array}{l}\text { Tidak } \\
\text { setuju }\end{array}$ \\
\hline 4 & $\begin{array}{l}\text { Kekerasan } \\
\text { ekonomi }\end{array}$ & 2,74 & $\begin{array}{l}64,2 \\
5\end{array}$ & Setuju \\
\hline \multicolumn{2}{|c|}{ Rata-rata } & 2,82 & 65,8 & Setuju \\
\hline \multicolumn{2}{|c|}{$\begin{array}{l}\text { Tabel } 1 . \\
\text { perempuan }\end{array}$} & \multicolumn{2}{|c|}{$\begin{array}{l}\text { Rekapitulasi } \\
\text { terhadap }\end{array}$} & $\begin{array}{r}\text { sikap } \\
\text { bentuk }\end{array}$ \\
\hline
\end{tabular}

kekerasan

\begin{tabular}{|l|l|l|l|l|}
\hline No & Pernyataan & $\begin{array}{l}\text { Rata- } \\
\text { rata }\end{array}$ & $\%$ & kategori \\
\hline 1 & $\begin{array}{l}\text { Kekerasan } \\
\text { fisik }\end{array}$ & 2,87 & 71,75 & Setuju \\
\hline 2 & $\begin{array}{l}\text { Kekerasan } \\
\text { psikologis }\end{array}$ & 2,29 & 57,28 & $\begin{array}{l}\text { Tidak } \\
\text { setuju }\end{array}$ \\
\hline 3 & $\begin{array}{l}\text { Kekerasan } \\
\text { seksual }\end{array}$ & 2,24 & 59,58 & $\begin{array}{l}\text { Tidak } \\
\text { setuju }\end{array}$ \\
\hline 4 & $\begin{array}{l}\text { Kekerasan } \\
\text { ekonomi }\end{array}$ & 2,71 & 59,43 & Setuju \\
\hline \multicolumn{2}{|l|}{ Rata-rata } & 2,73 & 62,01 & $\begin{array}{l}\text { Tidak } \\
\text { Setuju }\end{array}$ \\
\hline
\end{tabular}

Tabel 2. Rekapitulasi sikap laki-laki terhadap bentuk kekerasan

Berdasarkan rekapitulasi di atas dapat disimpulkan bahwa pemahaman perempuan lebih tinggi daripada laki-laki. Bentuk-bentuk kekerasan yang lebih dikenali dan disadari oleh masyarakat baik lakilaki dan perempuan adalah kekerasan fisik. Hal ini terlihat dari hasil pengetahuan perempuan $81,62 \%$ yang lebih tinggi dibandingkan dengan laki-laki 71,25\%.

Menurut (Hasanah, 2013) faktorfaktor dominan yang menjadi penyebab tindakan kekerasan terhadap perempuan dan anak dalam keluarga dan lingkungan sosial adalah budaya patriarki. Budaya patriarki merupakan sebuah struktur sosial dan praktik yang yang menempatkan laki-laki pada posisi dominan, menekan dan mengekploitasi jenis kelamin perempuan Walby (2014). Budaya ini sudah diterima dan diyakini oleh masyarakat sejak zaman dahulu (Noer, 2019).

Berdasarkan hasil penelitian di lapangan ditemukan bahwa budaya patriarki masyarakat di Nagari Siguntur, Tarusan masih tinggi dengan persentase $67,18 \%$ dari jenis kelamin perempuan dan $74,75 \%$ dari laki-laki. Artinya pemahaman masyarakat yang terlihat dari sikap perempuan terhadap faktor budaya patriarki lebih rendah dibandingkan laki-laki.

Pemahaman keliru terhadap agama telah melahirkan pandangan bahwa laki-laki adalah seorang pemimpin yang lebih unggul dari perempuan baik dari segi penghasilan, pendidikan dan lainnya (Umriana et al., 2016). Sesuai dengan hasil olahan data terlihat bahwa sikap perempuan $71,66 \%$ sedangkan lakilaki 76,25\%. Artinya bahwa kesalahpahaman laki-laki terhadap agama lebih tinggi dibandingkan 
perempuan. Masyarakat juga menganggap hal yang wajar apabila laki-laki dominan dan harus dipatuhi oleh perempuan.

Menurut Andini (2019) penyebab kekerasan terhadap perempuan dan anak adalah adanya warisan kekerasan yang dilakukan antar generasi. Anak yang melihat orang tuanya melakukan kekerasan cenderung akan melakukan hal yang sama di kemudian hari. Sesuai dengan hasil olahan data, menunjukan bahwa faktor peniruan terhadap masa lalu dilakukan oleh perempuan sebanyak $58,5 \%$ serta laki-laki $60,75 \%$.

\begin{tabular}{|l|l|l|l|l|}
\hline $\begin{array}{l}\text { N } \\
\mathrm{o}\end{array}$ & Penyataan & $\begin{array}{l}\text { Rata } \\
\text {-rata }\end{array}$ & $\%$ & $\begin{array}{l}\text { kategor } \\
\mathrm{i}\end{array}$ \\
\hline 1 & $\begin{array}{l}\text { Budaya } \\
\text { patriarki }\end{array}$ & 2,53 & $\begin{array}{l}67,1 \\
8\end{array}$ & Setuju \\
\hline 2 & $\begin{array}{l}\text { Pemahama } \\
\text { keliru yang } \\
\text { terhadap } \\
\text { agama }\end{array}$ & 2,77 & $\begin{array}{l}71,6 \\
6\end{array}$ & Setuju \\
\hline 3 & $\begin{array}{l}\text { Peniruan } \\
\text { terhadap } \\
\text { masa lalu }\end{array}$ & 2,34 & 58,5 & $\begin{array}{l}\text { Tudak } \\
\text { setuju }\end{array}$ \\
\hline \multicolumn{2}{|l|}{ Rata-rata } & 2,54 & $\begin{array}{l}65,7 \\
8\end{array}$ & Setuju \\
\hline
\end{tabular}

Tabel 3. Rekapitulasi sikap perempuan terhadap faktor penyebab kekerasan

\begin{tabular}{|l|l|l|l|l|}
\hline $\begin{array}{l}\text { N } \\
\mathrm{o}\end{array}$ & Penyataan & $\begin{array}{l}\text { Rata } \\
\text {-rata }\end{array}$ & $\begin{array}{l}\text { kategor } \\
\mathrm{i}\end{array}$ \\
\hline 1 & $\begin{array}{l}\text { Budaya } \\
\text { patriarki }\end{array}$ & 2,2 & $\begin{array}{l}74,7 \\
5\end{array}$ & Setuju \\
\hline 2 & $\begin{array}{l}\text { Pemahama } \\
\text { neliru yang } \\
\text { kerhadap } \\
\text { agama }\end{array}$ & 2,38 & $\begin{array}{l}76,2 \\
5\end{array}$ & Setuju \\
\hline 3 & $\begin{array}{l}\text { Peniruan } \\
\text { terhadap } \\
\text { masa lalu }\end{array}$ & 2,40 & $\begin{array}{l}60,1 \\
2\end{array}$ & $\begin{array}{l}\text { Tidak } \\
\text { setuju }\end{array}$ \\
\hline \multicolumn{2}{|l|}{ Rata-rata } & 2,32 & $\begin{array}{l}70,3 \\
7\end{array}$ & Setuju \\
\hline
\end{tabular}

Tabel 4. Rekapitulasi pengetahuan lakilaki terhadap faktor penyebab kekerasan
Berdasarkan rekapitulasi data di atas terlihat bahwa penerimaan lakilaki terhadap budaya patriarki lebih tinggi dibandingkan perempuan. Hal ini berarti bahwa baik laki-laki maupun perempuan belum menyadari bahwa budaya patriarki yang dijalankan masyarakat dapat mengakibatkan

perempuan direndahkan. Pemahaman agama yang keliru juga menjadi penyebab kekerasan di Nagari Siguntur.

Pencegahan dan penyelesaian tindakan kekerasan dapat dilakukan oleh masyarakat dengan cara melaporkan kejadian yang terjadi kepada mamak, perangkat desa, maupun lembaga terkait. Berdasarkan wawancara bersama beberapa masyarakat dapat disimpulkan bahwa pengetahuan masyarakat terhadap pencegahan dan penyelesaian tindakan kekerasan masih rendah. Hal ini terlihat dalam hasil wawancara yang menganggap bahwa permasalahan yang terjadi dalam rumah tangga adalah permasalahan pribadi yang tidak perlu dicampuri oleh orang lain. Alasan lainnya adalah korban tindakan kekerasan tidak mau terbuka terhadap permasalahan yang dihadapinya. Kurangnya sosialisasi yang diberikan oleh pemerintahan setempat kepada masyarakat juga berpengaruh terhadap tindakan kekerasan, sehingga masyarakat belum sepenuhnya mengetahui tindakan apa saja yang tergolong kekerasan.

Tindakan kekerasan yang terjadi dapat diminimalisir dengan meningkatkan pendidikan karekter bagi anak yang diperoleh di sekolah maupun di lingkungan keluarga. Dengan memperbaiki sikap anak maka akan meningkatkan rasa 
tanggung jawab yang ada pada dirinya (Arifa, 2019). Menurut (Adawiah, 2015) pencegahan terhadap tindakan kekerasan kepada anak dapat dilakukan dengan merubah pola asuh pada anak, serta selalu mensosialisasikan akibat dari tindakan kekerasan yang terjadi pada anak di kemudian hari.

Untuk menindaklanjuti tindakan kekerasan yang terjadi di lingkungan masyarakat maka perlu upaya yang serius dari pemerintah. Beberapa kegiatan dapat dilakukan adalah; mengadakan sosialisasi, sekolah ramah anak dan pendekatan yang lebih kepada masyarakat (Adiwilaga \& Aryanti, 2019).

\section{KESIMPULAN}

Berdasarkan analisis data yang dilakukan, dapat ditarik kesimpulan bahwa; Sikap masyarakat terhadap bentuk kekerasan masih rendah, sesuai hasil olahan data dimana lakilaki $61,14 \%$ dan perempuan $66,68 \%$. Adapun tindakan kekerasan yang lebih dikenali adalah bentuk kekerasan fisik.

Sikap masyarakat terhadap faktor penyebab kekerasan juga masih rendah. Hal ini dapat dibuktikan dari hasil olahan data penelitian yang mengungkapkan bahwa penerimaan terhadap budaya patriarki yang masih tinggi dengan persentase laki-laki $74,75 \%$ dan perempuan 67,18\%. Selanjutnya kekeliruan terhadap agama juga menjadi penyebab terjadinya tindakan kekerasan yang tidak disadari telah terjadi.

Sikap masyarakat terhadap pencegahan dan penyelesaian tindakan kekerasan di lingkungan masyarakat masih rendah. Hal ini dibuktikan dari hasil wawancara dari responden yang mengungkapkan bahwa masyarakat tidak mau terbuka, cuek, dan tidak peduli terhadap permasalahan yang dihadapi oleh tetangga. Serta kurangnya sosialisasi dari pemerintahan setempat.

Dari hasil penelitian ini ditemukan bahwa sikap laki-laki lebih baik dari pada perempuan dengan hasil penelitian yang tidak cukup signifikan. Hasil ini diperoleh dengan melihat kepada teori-teori serta metode penelitian yang digunakan.

Penelitian ini masih memiliki kekurangan karena singkatnya waktu penelitian serta kurang luasnya aspek yang dikaji. Sehingga penelitian selanjutnya hendaknya dapat mengumpulkan data penelitian dengan lebih maksimal. Adapun penelitian ini diharapkan dapat memberikan pengetahuan dan pemahaman kepada masyarakat terkait bentuk kekerasan, faktor penyebab kekerasan serta pencegahan dan penyelesaian kekerasan yang terjadi di kemudian hari.

\section{DAFTAR PUSTAKA}

UU No 35 Tahun 2014 Perubahan Atas UU No 23 Tahun $2020 \quad$ Tentang Perlindungan anak.

Undang-Undang Dasar Republik Indonesia 1945

UU No 23 Tahun 2004 tentang Penghapusan

Kekerasan Dalam Rumah Tangga.

UU No 39 Tahun 1999 tentang Hak Asasi Manusia

Adawiah, R. Al. (2015). Upaya Pencegahan Kekerasan Terhadap Anak. 279-296.

Adiwilaga, R., \& Aryanti, R. (2019). Implementasi Peraturan Daerah Kabupaten Bandung Oleh Pusat 
Pelayanan Terpadu Pemberdayaan Perempuan Dan Anak ( P2tp2a) Kabupaten Bandung. 3(1), 28-38.

Andini, T. M., Sulistyowati, T., Alifatin, A., Sudibyo, R. P., Raya, J., \& Email, M. (2019). Identifikasi Kejadian Kekerasan pada Anak di Kota Malang Identification of Violence in Children in Malang City. 2(1), 13-28.

Arifa, F. N. (2019). 13 pencegahan kekerasan melalui pendidikan karakter.

Fatmariza, F., Muchtar, H., Dewi, S. F., Irwan, I., Putra, I., Suasti, Y., \& Febriani, R. (2020). Peningkatan Pengetahuan dan Pemahaman Masyarakat Nagari Pasie Laweh tentang Kekerasan Terhadap Perempuan dan Anak melalui Penyuluhan. VIVABIO: Jurnal Pengabdian Multidisiplin, 2(1), 816.

Hasanah, H. (2013). Anak Dalam Rumah Tangga Perspektif. 9, 159178.

Hermawan, H. (n.d.). Metode kuantitatif.

Iii, B. A. B., Penelitian, A. J., \& Moleong, L. J. (n.d.). Metode Penelitian. 48-60.
Noer, K. U. (2019). Mencegah Tindak Kekerasan pada Anak di Lembaga Pendidikan. 14(1), 47-66.

Rifa, M. (2019). Kekerasan terhadap Perempuan dalam Ketimpangan Relasi Kuasa: Studi Kasus di Rifka Annisa Women' s Crisis Center. 14(2), 175-190. https:/ / doi.org/10.21580/sa.v14i 2.4062

Santoso, A. B. (2019). Kekerasan Dalam Rumah Tangga ( KDRT ) Terhadap Perempuan: Perspektif Pekerjaan Sosial. 10(1), 39-57.

Surtinah, A. N. I., Studi, P., Ilmu, M., Pascasarjana, P., \& Surakarta, U. M. (2017). Studi Tentang Efektifitas Hukum Penanganan Kasus Kekerasan Terhadap Perempuan Di Pelayanan Terpadu Perempuan dan Anak Surakarta ( PTPAS ).

Sugiyono, S. (2010). Metode penelitian kuantitatif dan kualitatif dan R\&D. Alfabeta Bandung.

Umriana, A., Fauzi, M., \& Hasanah, H. (2016). Penguatan Hak Asasi Perempuan Dan Kesetaraan Gender Melalui. 12, 41-60. 